\title{
Feasibility Analysis of Freshwater Fish Farming Business at Karya Mulya Fish Farming Group, Banyumas Regency
}

\author{
Mustika Palupi ${ }^{1 *}$, Ren Fitriadi ${ }^{1}$, Muh. Sulaiman Dadiono ${ }^{1}$, Rika Prihati Cahyaning \\ Pertiwi $^{2}$ and Candro Dea Bagaskara Super Yudhistira ${ }^{1}$ \\ ${ }^{1}$ Aquaculture Study Program, Faculty of Fisheries and Marine Sciences, Jenderal Soedirman \\ University, Jl. Dr Soeparno, Karangwangkal, Purwokerto, Central Java 53122, Indonesia \\ ${ }^{2}$ Aquatic Resource Management Study Program, Faculty of Fisheries and Marine Sciences, Jenderal \\ Soedirman University, Jl. Dr Soeparno, Karangwangkal, Purwokerto, Central Java 53122, Indonesia
}

*Correspondence :

mustika.palupi@unsoed.ac.id

Received : 2020-11-09

Accepted : 2021-08-05

Keywords :

Business analysis, Fish farming, Freshwater fish, Banyumas

\begin{abstract}
This study aims to determine the feasibility of freshwater fish farming as an effort to support the minapolitan area of the Banyumas Regency. The research was carried out in Karang Lewas District. Data collection was carried out proportionally by interviewing the fish farmers of each fish farming group. Data analysis on the feasibility of fish farming was performed using the $\mathrm{B} / \mathrm{C}$ ratio, PP, and BEP (Break-Even Point) criteria. The analysis method of the business feasibility was an analysis of business costs and income. Results of the analysis of B/C ratio value in fish farming was 1.13 to 1.69 , BEP calculation used data according to the respondents, while the Payback Period (PP) of the fish farming ranged between 1.00-1.49 meaning that the capital return in less than 5 years. Those values state that the activities of freshwater fish farming have a capital return of more or less over 1 - 1.5 years. It shows that the business of freshwater fish farming in both hatcheries and fish rearing is feasible to maintain.
\end{abstract}

\section{INTRODUCTION}

Banyumas Regency is one of the pilot areas of minapolitan development along with 24 centers of fish farming production in Indonesia in 2011. Minapolitan region is located in 10 districts, namely Kedungbanteng, Karanglewas, Baturraden, Sumbang, Kembaran, Sokaraja, Sumpiuh, Kemrajen, Cilongok, and Ajibarang. In Banyumas, several types of fish such as nilem fish (bony lip barb), carp, catfish, Java barb, goldfish, Nile tilapia, and tilapia fish have long been cultivated. Fish products in the market are not only consumption-sized fish but also fish seeds in various sizes and even spawning eggs. In addition to meeting domestic needs, these fish have been targeted to export commodities, both in the form of whole fish and fillets.

The main factor of failure in fish production other than in aquaculture and fish feed management is aquaculture management (Fitriadi et al., 2020). The problems faced by most freshwater fish farmers in Banyumas are limited capital and equipment, lack of knowledge about market and technology information, as well as lack of skills, policies, and institutional support. Those problems and weaknesses may lead to the failure of freshwater fish farming activities. The failure is likely caused by errors of planning, errors in estimating the market, and so on. Calculation of the financial 
aspects including the capital, costs, and revenue in a specific period is necessary to improve financial profit. Several preceding studies on the financial aspects of fish farming in Banyumas had been carried out, for example, a study by Fathurrohman (2013) stating that fishery agribusiness activities in Sokaraja district of Banyumas Regency are the center of carp rearing business, it is a side activity to earn additional income. It was further explained by Junita and Utami (2019) in their research on the production factors of carp hatchery in Kedungbanteng District of Banyumas Regency; it stated that capital or financial aspect is a crucial production factor. There has been no research analyzing the activities of the fish farming business in various regions of Banyumas Regency.

The followings are variables will be observed in the fish rearing activity: seed, feed, force labor, electricity, maintenance of assets, license, transportation, fertilizers, and drugs, etc. Meanwhile, business prospects can be determined based on the calculation of BEP, Payback Period (PP), and Benefit-Cost Ratio (B/C Ratio) (Palupi et al., 2020). Based on these variables, it can be concluded whether or not the freshwater fish farming activities in the District of Karang Lewas, Banyumas, are feasible to maintain. This analytical study aims to determine the business feasibility of freshwater fish farming (in terms of revenue analysis of costs and profits) in Karang Lewas District of Banyumas Regency.

\section{METHODOLOGY}

\section{Place and Time}

This research was conducted from February - June 2020. The study was conducted in Karang Lewas District which is one of the centers for fish farming of carp, pomfret, Nile tilapia, and catfish with a total production of 337,000 fish per production.

\section{Research Materials}

This study made use of primary data from interviews, Focus Group Discussion, as well as secondary data. The primary data were obtained from direct observation on-site and direct interviews with fish farmers, as well as assessment of market aspect, technical or operational aspect, the management or organizational aspects, and financial aspect. The secondary data was taken from various books explaining fish farming, preceding studies, supplementary books, internet access as well as information obtained from associated institutions, for example, fishery statistic data from the Department of Marine and Fisheries of Central Java was used as a relevant reference for this research.

\section{Research Design}

The method used in this study was the descriptive-analytical method that focused on problem-solving comprising facts or factual circumstances in the field.

\section{Work Procedure \\ Business Feasibility Analysis}

Primary data collection includes those from the associated institutions. The collected data was then tabulated and analyzed for business feasibility using the following:

Cost and revenue analysis was done by calculating components of the cost incurred by the fish farmers including the cost of breeding, seeds, land rent, maintenance of equipment, fertilizer, feed, electricity, dolomite, etc. As well as the income calculation which is the difference between revenues and costs incurred, so that profit from fish farming activities can be calculated.

A business feasibility analysis was carried out using BEP, B/C ratio, and PP. Costs in the fish farming business are classified as follows: initial cost which means the costs spent before the business starts to run, such as capital, etc.; and operational cost which is the costs incurred when the fish farming business 
runs and yields products. After calculating the revenue of the fish farming business, the calculation of initial cost, production or operational costs, and revenues were used to calculate $\mathrm{BEP}, \mathrm{B} / \mathrm{C}$ ratio, and $\mathrm{PP}$.

The Payback Period is a period of returning the total amount of investment, calculated using cash flow from the beginning of the project up to the net flow of additional production; hence, it reaches the total amount of capital investment. According to Nurmalina et al. (2018), the Payback Period can be mathematically formulated as follows:

$\mathrm{PP}=\frac{\text { investment }}{\text { profit }}$

It uses the following criteria: $\mathrm{PP}<5$ years means that the business has a rapid PP so it is feasible to operate, while PP > 5 years means that the business has a slow PP so it is not feasible to operate.

According to Bakti et al. (2010), Net Benefit-Cost Ratio is the amount of additional benefit for each additional cost for one unit of time. B/C ratio is the comparison between the present value of the positive value net benefit and the negative value net benefit. The formula used is as follows:

$\mathrm{B} / \mathrm{C}$ Ratio $=\frac{\text { revenue }}{\text { total cost }}$

$\mathrm{B} / \mathrm{C}$ Ratio $>1$ means that the business is feasible or profitable, while $\mathrm{B} / \mathrm{C}$ Ratio $<1$ means that the business is not feasible nor profitable.

\section{Data Analysis}

The data analysis used in this research is descriptive, and business feasibility analysis. Descriptive analysis is an analysis used to describe the results of observations following the reality in the field regarding something being studied (Neliyana et al., 2014).

\section{RESULTS AND DISCUSSION}

Freshwater fish farming business run by Karya Mulya 2 group in Karanglewas District, Banyumas Regency, indicated that fish farming business such as the cultivation of pomfret, carp, and tilapia is concentrated in certain districts. The cost incurred for fish farming including explicit and implicit costs is used to calculate income and profits (Hidayati, 2019).

Table 1. Costs and income of freshwater fish farming.

\begin{tabular}{lllll}
\hline Components & Carp Rearing & Carp Hatchery & Pomfret Hatchery & Tilapia Rearing \\
\hline Land Area $\left(\mathrm{m}^{2}\right)$ & 1,320 & 2,320 & 930 & 4,929 \\
Explicit Costs (IDR) & 4,440 & 31,235 & 19,447 & 40,000 \\
Implicit Costs (IDR) & 1,000 & 7,000 & 7,000 & 15,000 \\
Total Costs (IDR) & 5,440 & 38,235 & 26,447 & 55,000 \\
Income (IDR) & 33,700 & 49,000 & 31,000 & 70,000 \\
Profit (IDR) & 28,260 & 10,765 & 4,553 & 15,000 \\
\hline
\end{tabular}

The results show that land area in the fish farming business, both rearing, and hatchery, analytically affected the fish farmers' income. The larger the land area, the more fish can be reared which resulted in a higher income. This is following the opinion of Sutiani et al. (2020) stating that the income of the fish farming business is strongly influenced by the scale of the business, moreover, the facility of the fish farming supported by capital will determine the results. It is further explained by Pujastuti (2012) that fish farming is influenced by technology, one of which is the type of feed technology resulting in fish growth increase and increase income.

Income from the hatchery business is higher than that in the rearing business because the hatchery has a faster turnover since the fish seeds will be cultured only in 21 to 60 days depends on the farmers' decision to harvest the fish based on its size. To maximize the income of catfish cultivators, it is necessary to increase the number and area of ponds and develop 
aquaculture businesses, apply good maintenance and cultivation methods (Jatnika et al., 2014). It is following the opinion of Mahyudin (2011) stating that pomfret fish hatchery has a faster capital turnover with a smaller risk compared with that of rearing business. The fish size affects the selling price; the bigger the fish, the higher the farmers' income. In addition, in the hatchery business, a productive tilapia broodstock can be used a maximum of 5 times a year, while carp broodstock can be used twice a year.

Table 2. BEP value.

\begin{tabular}{lllll}
\hline Components & $\begin{array}{c}\text { Carp Rearing } \\
\text { (IDR/Kg) }\end{array}$ & $\begin{array}{c}\text { Carp Hatchery } \\
\text { (IDR/Fish) }\end{array}$ & $\begin{array}{c}\text { Pomfret } \\
\text { Hatchery } \\
\text { (IDR/Fish) }\end{array}$ & $\begin{array}{c}\text { Tilapia Rearing } \\
\text { (IDR/Fish) }\end{array}$ \\
\hline BEP of Product & 376 & 8,878 & 28,175 & 12,25 \\
Production & 3,000 & 22,000 & 23,000 & 4,000 \\
BEP of Price & 2,998 & 1,513 & 121 & 13,750 \\
Market Price & 25,000 & 4,000 & 1,000 & 17,500 \\
\hline
\end{tabular}

BEP is the value of the break-even point where there is a balance between the revenue and the total cost, which means that the revenue is equal to the total cost that has been incurred (Winarti, 2017). BEP analysis can be used as a business plan for it can be calculated by the amount of production $(\mathrm{kg})$ and the revenue (IDR) to make a profit ana $\mathrm{d}$ hence the price of fish can be calculated (in IDR or $\mathrm{kg}$ ). Therefore, the fish farmers earn profit from the total cost of production (Suratiyah, 2008). BEP or break-even point in fish farming occurs when the total cost incurred is equal to the total production, while BEP of products in fish farming may occur when the total cost is equal to the average price of fish in the market.

From Table 2, it can be concluded that the freshwater fish farming business is above the BEP of product and the BEP of price. BEP was calculated following the respondent. Most of the fish farmers cultivate fish on a land of $1,000-5,000$ $\mathrm{m}^{2}$. Results of the $\mathrm{B} / \mathrm{C}$ ratio and $\mathrm{PP}$ calculation for three types of freshwater fish, namely, carp, tilapia, and pomfret in Sleman Regency are presented in Table 3.

Table 3. Value of $\mathrm{B} / \mathrm{C}$ ratio and Pay Period (PP).

\begin{tabular}{lllll}
\hline Component & Carp Rearing & Carp Hatchery & $\begin{array}{l}\text { Pomfret } \\
\text { Hatchery }\end{array}$ & Tilapia Rearing \\
\hline B/C Ratio & 1.69 & 1.13 & 1.55 & 1.27 \\
PP & 1.15 & 1.43 & 1.49 & 1 \\
\hline
\end{tabular}

B/C Ratio business analysis is one of the business feasibilities analyses to determine whether or not a business or a product is feasible to carry out. $\mathrm{B} / \mathrm{C}$ ratio value of the fish farming was $1.13-1.69$, indicating that the fish farming business, both hatchery, and rearing, was feasible to carry out. When the value of $\mathrm{B} / \mathrm{C}>1$, it means that the cash income can cover the cash costs/expense, therefore, it is feasible for sustainable investment (Haming and Basalamah, 2003).
PP value of the fish farming ranged from 1.00 to 1.49 which means a return of the capital is in less than 5 years. This value states that the fish farming activities have an annual return of capital for more or less 1 year to 1.5 years. The payback period is considered rapid as some hatchery farmers had harvested the fish after $2-3$ months culture and some farmers reared the fish in a bigger size, around $5-7 \mathrm{~cm}$, resulting in a shorter farming period. According to Wati (2016), the capital return is considered rapid if the 
$\mathrm{PP}$ value is $<5$ years and is considered slow if the PP value is $>5$ years. The faster return of a project investment indicates a better project since it has a smooth capital turnover (Yacob, 2003: Palupi et al., 2021). Husnan and Suwarsono (1993) stated that the faster return of a business capital indicates a better project because the returned capital can be expended to finance other projects.

\section{CONCLUSION}

Results of the study indicate that freshwater fish farming in Banyumas Regency is financially feasible. B/C Ratio value obtained in the study was 1.13 1.69 and the Payback Period value was $1.00-1.49$.

\section{ACKNOWLEDGMENT}

The authors would like to especially thank the grants-in-aid from the University of Jenderal Sudirman, That Provided the Research Program Grant for the Beginner Lecturer in the Budget Year of 2020 (UNSOED Grant) as financial support for this research.

\section{REFERENCES}

Bakti, T.D., Sumanjaya, R. and Hasution, S.H., 2010. Pengantar Ekonomi Makro. USUpress : Medan. p.124.

Fathurrohman, Y.E., 2013. Strategi Pengembangan Agribisnis Ikan Gurami Di Kabupaten Banyumas. Skripsi, Fakultas Pertanian Universitas Sebelas Maret. https://d igilib.uns.ac.id/dokumen/detail/29 986

Fitriadi, R., Palupi, M., Kusuma, B. and Prakosa, D.G., 2020. Manajemen Pemberian Pakan pada Budidaya Ikan Kerapu Macan (Epinephelus fuscogutattus) di Desa Klatakan, Situbondo, Jawa Timur. Samakia: Jurnal Ilmu Perikanan, 11(2), pp.6670. https://journal.ibrahimy.ac.id/i ndex.php/JSAPI/issue/view/109

Haming, M. and Basalamah, S., 2003. Studi kelayakan investasi: Proyek dan Bisnis.Penerbit PPM : Jakarta. p.351.

Hidayati, S., 2019. Teori Ekonomi Mikro. Penerbit Unpam Press. Universitas Pamulang: Tangerang. p.214.

Husnan, S. and Suwarsono, 1993. Studi kelayakan proyek : konsep, teknik dan penyusunan laporan. Penerbit UPP AMP YKPN : Yogyakarta. p.358.

Ibrahim, H.M.Y., 2003. Studi Kelayakan Bisnis. Edisi Revisi. PT. Rineka Cipta: Jakarta, p.249.

Jatnika, D., Sumantadinata, K. and Pandjaitan, $\quad$ N.H., 2014. Pengembangan Usaha Budidaya Ikan Lele (Clarias sp.) di Lahan Kering di Kabupaten Gunungkidul, Provinsi Daerah Istimewa Yogyakarta. MANAJEMEN IKM: Jurnal Manajemen Pengembangan Industri Kecil Menengah, 9(1), pp.96-105. https://doi.org/10.2924 4/mikm.9.1.96-105

Junita, R. and Utami, P., 2019. Identifikasi penggunaan faktor produksi pembenihan ikan gurami pada pokdakan pamuji inggil desa beji, kecamatan kedungbanteng, kabupaten banyumas. Proceeding: Optimalisasi Sumberdaya Lokal Untuk Pembangunan Pertanian Terpadu dan Berkeadilan. ISBN 978-602-6697-47-9. http://digital.li brary.ump.ac.id/id/eprint/657

Mahyuddin, K., 2011. Usaha pembenihan ikan bawal di berbagai wadah. Penebar Swadaya Grup : Jakarta. p.140.

Neliyana, Wiryawan, B., Wiyono, E.S. and Nurani, T.W., 2014. Analysis Financial Fisheries of Purse Seine in Lampulo Fishing Port Banda Aceh Provinsi Aceh). Marine Fisheries: Journal of Marine Fisheries Technology and Management, 5(2), pp.163-169. https://doi.org/10.292 44/jmf.5.2.163-169

Nurmalina, R., Sarianti, T. and Karyadi, A., 2018. Studi kelayakan bisnis. Penerbit IPB Press : Bogor.

Palupi, M., Fitriadi, R., Dadiono, M.S., Yonarta, D. and Kusuma, R.O., 
2021. Profitability Analysis of Tiger Grouper Hatchery (Epinephelus fuscoguttatus) Household Scale in Kelatakan Village, Situbondo, East Java. Journal of Aquaculture and Fish Health, 10(2), pp.192-198. http://d x.doi.org/10.20473/jafh.v10i2.193 54

Palupi, M., Fitriadi, R., Prakosa, D.G. and Pramono, T.B., 2020. Analisis Kelayakan Usaha Pembenihan Ikan Kerapu Cantang (Epinephelus sp.) di Desa Blitok, Situbondo. Samakia: Jurnal Ilmu Perikanan, 11(2), pp.101-107. https://journal.ibrahim y.ac.id/index.php/JSAPI/issue/vie $\mathrm{w} / 109$

Pujastuti, P., 2012. Analisis Usaha Budidaya Ikan Gurami Di Kelompok Budidaya Ikan Mina Lestari, Turus Tanjungharjo, Nanggulan, Kulon Progo. Agricultural Socio-Economics Journal (AGRISE), 12(2), p.145156. https://agrise.ub.ac.id/index.p hp/agrise/article/view/91

Suratiyah, K., 2008. Ilmu Usaha tani. Penebar Swadaya. : Jakarta. p,124.

Sutiani, L., Bachtiar, Y. and Saleh, A., 2020. Analisis Model Budidaya Ikan Air Tawar Berdominansi Ikan Gurame (Osphronemus Gouramy) di Desa Sukawening, Bogor, Jawa Barat. Jurnal Pusat Inovasi Masyarakat (PIM), 2(2), pp.207214. https://journal.ipb.ac.id/index .php/pim/article/view/30390

Wati, M., 2016. Analisis Payback Period Sebagai Dasar Kelayakan Investasi. Jurnal Daya Saing, 2(2), pp.117124. https://doi.org/10.35446/day asaing.v2i2.54

Winarti, L., 2017. Analisis break even point dan risiko pendapatan usahatani ikan Nila (Oreochromis niloticus) keramba jaring apung di Desa Pematang Panjang Kecamatan Seruyan Hilir Timur Kabupaten Seruyan. Jurnal Ilmu Hewani Tropika (Journal of Tropical Animal Science), 6(1), pp.11-14. 